\title{
Oral Hypoglycaemic Drugs in Alloxan-Induced Diabetes Mellitus in Dogs
}

\author{
É. BALOGH${ }^{1}$, M. TÓTH², G. BÖLCSHÁZI ${ }^{3}$, ZS. ABONYI-TÓTH ${ }^{4}$, E. KOCSIS ${ }^{5}$, G. SEMJÉN ${ }^{1}$
}

${ }^{1}$ Department of Pharmacology and Toxicology, Faculty of Veterinary Science, Szent István University, Budapest, Hungary

${ }^{2}$ Molecular Genetic Research Group, Hungarian Academy of Sciences; Department of Cardiology, Semmelweis University; Szentágothai János Knowledge Centre, Budapest, Hungary

${ }^{3}$ Betegeuce Ltd., Budapest, Hungary

${ }^{4}$ Department of Biomathematics and Informatics, Faculty of Veterinary Science, Szent István University, Budapest, Hungary

${ }^{5}$ Gottsegen György National Institute of Cardiology, Budapest, Hungary

Received November 21, 2007

Accepted April 14, 2008

\begin{abstract}
Balogh É., M. Tóth, G. Bölcsházi, Zs. Abonyi-Tóth, E. Kocsis, G. Semjén: Oral Hypoglycaemic Drugs in Alloxan-Induced Diabetes Mellitus in Dogs. Acta Vet. Brno 2008, 77: 363-371.

The effect of the alpha-glycosidase inhibitor acarbose, the insulin sensitiser metformin and the insulin secretiser gliclazide on blood glucose level of dogs were examined in experimental diabetes.

Dogs were randomly divided into three groups. During the first week of the experimental period control blood glucose data were determined. During the subsequent five weeks, the first group $(n=6)$ was administered acarbose $(200 \mathrm{mg} / \mathrm{dog} /$ day $)$, the second $(\mathrm{n}=5)$ was treated with metformin (1700 mg/dog/day), and the third was given gliclazide (160 mg/dog/day). The drug was administered twice daily when feeding at 7:00 and 15:00 h.

The average difference between postprandial and fasting blood glucose was determined for the treated and the control period, and the statistical significance of their difference (mean decrease) was evaluated by two-sampled $t$-test.

The mean decrease in blood glucose was $0.49 \mathrm{mmol} / 1(P=0.09)$ for acarbose, $1.15 \mathrm{mmol} / 1$ $(P=0.01)$ for metformin, and $0.08 \mathrm{mmol} / 1(P=0.88)$ for gliclazide.

According to the results of statistical evaluation, metformin was the only drug that caused a significant decrease in postprandial blood glucose.
\end{abstract}

Acarbose, metformin, gliclazide, blood glucose level, diabetes mellitus, therapy

Dogs with diabetes mellitus (DM) are usually treated with insulin. Insulin is a protein and, as such, not suitable for oral administration. Thus, it is administered once or several times daily by the subcutaneous route. Adjustment of the blood glucose concentration demands long hospital care, and subsequently the owner constantly has to keep a strict schedule at home. These reasons urge researchers to find an alternative way for the treatment of diabetic dogs.

In human medicine, several drug families with different modes and sites of action are used in the early stage of type 2 (non-insulin dependent) DM for the oral treatment of this disease. Some of these drugs are used in cats, but hardly any data are available on their effectiveness in dogs.

The main groups of oral antidiabetic drugs used in human medicine (Fövényi et al. 2001) are:

1. Carbohydrate absorption inhibitors (e.g. acarbose);

2. Insulin sensitisers (biguanides such as metformin, thiazolidinedions, peroxisome proliferator-activated gamma receptor agonists);

Address for correspondence:

Éva Balogh

Department and Clinic of Internal Medicine

Faculty of Veterinary Science, Szent István University

H-1078 Budapest, István u. 2, Hungary
Phone: 036-1-478-4138

Fax: 036-1-478-4137

E-mail: balogheva@freemail.hu

http://www.vfu.cz/acta-vet/actavet.htm 
3. Insulin secretisers. Some insulin secretisers initiate insulin secretion (sulphonylureas, such as gliclazide, meglitinides, $\mathrm{N}$-acylphenylalanine), while others potentiate insulin secretion (certain amino acids like arginine, transmitters like acetylcholine, and peptides like glucagon) (Kecskeméti et al. 2002).

In humans, acarbose retards the digestion and absorption of carbohydrates through enzyme inhibition and, hence, reduces the increase of blood glucose concentration after carbohydrate load in humans. Acarbose inhibits the alpha-glucosidases, which include enzymes produced in the brush border of the small intestine. Sucrase, maltase, isomaltase, glucomaltase, lactase and other enzymes function to digest complex carbohydrates and disaccharides into monosaccharides, which are subsequently absorbed through the small intestine. Acarbose competitively and reversibly inhibits these enzymes, delaying the hydrolysis of complex carbohydrates without affecting the absorption of the glucose molecule. Carbohydrate absorption then shifts to more distal parts of the intestine. Carbohydrates that reach the large intestine are metabolised by colonic bacteria into fatty acids for absorption (Robertson et al. 1999). Acarbose does not cause a malabsorptive state, nor does it decrease the hepatic glucose output (Cowan and Bunch 2001).

The side effects of acarbose are generally mild (Behrend 2002). Gastrointestinal disturbances, particularly flatulence and diarrhoea may occur due to the gases from nonabsorbed carbohydrates in the colon in human patients (Godbout and Chiasson 2007; Hanefeld and Schaper 2008), whereas dogs in one study also developed semi-soft to watery stool, while flatulence was not observed (Robertson et al. 1999).

Total serum triglyceride concentrations are usually but not always decreased, but there is little or no change in total serum cholesterol concentrations (Nelson et al. 2000).

In human medicine, acarbose is indicated as an adjunct to diet or diet plus sulphonylurea in non-insulin dependent diabetics, and it may compensate at least in part for the slow absorption of subcutaneous insulin in insulin-dependent diabetics.

Acarbose is poorly absorbed from the gastrointestinal tract. It is extensively degraded in the bowel and excreted via the faeces and urine (Fövényi et al. 2001).

Metformin hydrochloride is a biguanide hypoglycaemic agent used in the treatment of type 2 ("non-insulin dependent") diabetes mellitus not responding to dietary modification. Biguanides do not stimulate insulin release, but they require the presence of some insulin to exert a hypoglycaemic effect. Metformin delays the absorption of glucose from the gastrointestinal tract, increases the insulin sensitivity of cells, suppresses hepatic gluconeogenesis (Cusi et al. 1996; Féry et al. 1997) and enhances glucose transport in fat and muscle (Lenhard et al. 1997). It does not usually lower blood glucose concentrations in non-diabetic subjects. The molecular mechanism of biguanides involved in lipid and carbohydrate metabolism is unclear. Metformin seems to promote catabolism by stimulating aerobic respiration, basal lipolysis and fatty acid oxidation (Lenhard et al. 1997).

Metformin causes gastrointestinal adverse effects (Belcher et al. 2005) including anorexia, nausea and diarrhoea. In humans, lactic acidosis can be a rare but serious, sometimes fatal, side effect of metformin treatment. Lactic acidosis is due to the inhibition of gluconeogenesis and the increase of glucose utilisation in peripheral tissues (Féry et al. 1997). Metformin hydrochloride is absorbed from the gastrointestinal tract and is excreted unchanged in the urine (Pentikainen et al. 1979).

Gliclazide is a sulphonylurea hypoglycaemic agent. Sulphonylureas induce insulin secretion in the pancreatic beta cells and inhibit glucogenolysis and gluconeogenesis in the liver. Through improving insulin binding to surface receptors, they also enhance the insulin sensitivity of target cells. Furthermore, there is in vitro evidence for an increased number of insulin receptors in tissues of action (DeFronzo 1999).

In dogs, first-generation sulphonylureas exert a positive inotropic effect (BallagiPordány et al. 1991). 
Adverse effects of sulphonylureas in humans include gastrointestinal disturbances (nausea, vomiting, anorexia or increased appetite, diarrhoea), skin rashes and hypersensitivity reactions (Fövényi et al. 2001).

Gliclazide is readily absorbed from the gastrointestinal tract. It is extensively metabolised in the liver to metabolites without significant hypoglycaemic activity. Both unchanged drugs and metabolites are excreted in the urine with the exception of gliquidone which is metabolised entirely through the liver and excreted with the bile (Fövényi et al. 2001).

In this work, the effect of acarbose, metformin and gliclazide on the blood glucose level of alloxan-diabetic dogs was studied.

\section{Materials and Methods}

Seventeen clinically healthy, mixed-breed, medium-sized dogs (weighing $25 \pm 5 \mathrm{~kg}$ ) of both sexes were used in this study.

All experiments were carried out in compliance with the Guide for the Care and Use of Laboratory Animals (USA NIH Publication No. 85 - 23, revised in 1985). The experiments were approved by the National Scientific Committee on Animal Experimentation.

The animals were housed in individual cages with a mean environmental temperature of $20{ }^{\circ} \mathrm{C}$ for $12 \mathrm{~h}$ in artificial light and $12 \mathrm{~h}$ in darkness. The dogs received complete dog food $(60 \%$ carbohydrate, $25 \%$ protein, $15 \%$ fat) twice a day (at 7:00 and 15:00 h) and water ad libitum.

Haemogram, serum alanine transaminase (ALT), alkaline phosphatase (ALP), amylase, lipase, triglyceride (TG) and total cholesterol (TC) were tested before the induction of diabetes and subsequently at weekly intervals during the experiment. Blood glucose levels and plasma glucose disappearance rate from a 7-point glucose tolerance test were also controlled before alloxan administration. All laboratory data of the experimental animals were normal.

Diabetes was induced by a single intravenous infusion of $0.1246 \mathrm{mg} / \mathrm{kg}$ body weight (b.w.) alloxan (SigmaAldrich; St. Louis, USA).

Fasting blood glucose (FBG) was tested 7 and 14 days after the alloxan treatment. Dogs having moderately elevated (6.5 - $8.3 \mathrm{mmol} / \mathrm{l}) \mathrm{FBG}$ were selected for further study.

During the first week of the study the dogs did not receive any drug. Daily fasting and postprandial blood glucose levels, measured in that period, served as control data. On day 8 the dogs were randomly divided into three groups. The first group of six dogs was administered $200 \mathrm{mg}$ acarbose (Glucobay - Bayer; Leverkusen, Germany) $(9.1 \pm 0.8 \mathrm{mg} / \mathrm{kg}$ bw) daily. The second group of five dogs was treated with metformin (Meforal Berlin-Chemie; Berlin, Germany) $1700 \mathrm{mg}$ per dog per day $(60.9 \pm 6.4 \mathrm{mg} / \mathrm{kg} \mathrm{bw})$. The third group of six dogs were given $160 \mathrm{mg}$ gliclazide daily (Diaprel - Servier; Gidy, France) $(6.1 \pm 0.7 \mathrm{mg} / \mathrm{kg} \mathrm{bw})$. The daily dose of drug was divided into two equal parts and administered at the time of feeding.

Blood glucose level was measured twice a day. The first sampling was done just before feeding (FBG), and the second 60 min later for the determination of postprandial blood glucose (PPBG) level. Blood samples for haemogram and biochemical panel (ALT, ALP, amylase, lipase, TG, TC) were taken on the first day of the experiment and then weekly. EDTA tubes for haemogram and heparinised tubes for biochemical data were used. Biochemical samples were processed within $24 \mathrm{~h}$.

Blood samples for insulin measurement were collected into heparinised tubes also weekly with the exception of the gliclazide group, where samples were taken every third day. Heparinised samples were centrifuged immediately (3500 rpm, $5 \mathrm{~min}$ ), the plasma was separated and stored at $-20^{\circ} \mathrm{C}$ until assayed.

ALT was measured with ALT reagent manufactured by Roche (Basle, Switzerland) IFCC Hitachi, and the rest of the biochemical data with reagents from Diagnosticum Co. Ltd. (Budapest, Hungary).

Blood glucose was measured with D-Cont Glucotester (Lilly; Indianapolis, USA). Haematology was done using a Baker 7000 Haematological Automat (Baker Instruments; New York, USA).

Insulin was measured with BI-Insulin IRMA (Cis bio International, Shering; Wien, Austria).

The differences between postprandial and fasting blood glucose concentrations were used for the statistical evaluation. The difference between blood glucose after and before feeding (PPBG-FBG) resulted in blood glucose difference (BGD) data. Daily BGDs were averaged for the control and the treated period in each dog. Their difference resulted in treatment difference (TD) for each dog. The average of TDs gave the mean decrease (MD) in blood glucose level for each drug. The significance of MD was statistically analysed by the two-sampled paired $t$-test. The data were checked using the Shapiro-Wilk normality test, $P=0.62$ for acarbose, $P=0.65$ for metformin, and $P=0.83$ for gliclazide.

\section{Results}

The general behaviour of the dogs was normal. In some cases sleepiness or thirstiness was observed. From the third week of treatment, some of the dogs showed nausea or 
diarrhoea. During the treatment period, FBG and PPBG levels varied in the normal or slightly elevated range $(4.0-8.5 \mathrm{mmol} / \mathrm{l})$ in the metformin and acarbose groups, while in the gliclazide group severe hyperglycaemia (up to $22.4 \mathrm{mmol} / \mathrm{l}$ ) was detected several times in three dogs.

The MD was $0.49 \pm 0.58 \mathrm{mmol} / \mathrm{l}(P=0.09)$ for acarbose treatment, $1.15 \pm 0.64 \mathrm{mmol} / 1$ $(P=0.01)$ for metformin and $0.08 \pm 1.33 \mathrm{mmol} / \mathrm{l}(P=0.88)$ for gliclazide (Figs 1,2 , and 3$)$.

\section{$\square$ control $\square 200 \mathrm{mg} / \mathrm{kg} \mathrm{bw}$}

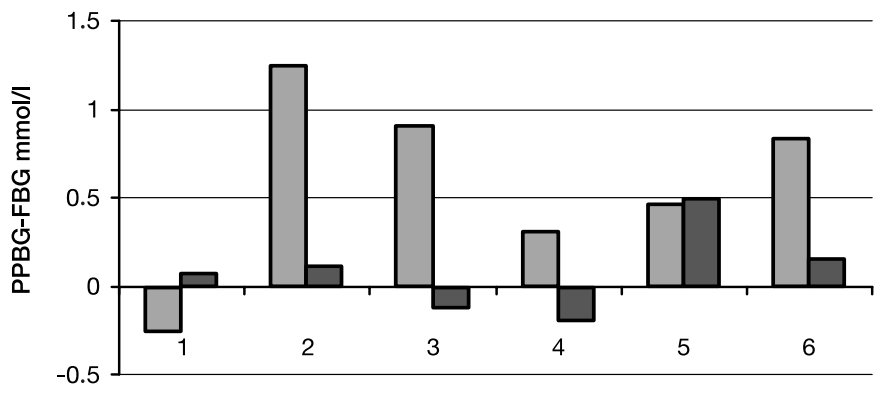

ID number of dogs

Fig. 1. Average blood glucose differences (PPBG-FBG) before and after treatment with $200 \mathrm{mg}$ acarbose in alloxan-diabetic dogs

$P$ value $=0.09$

Mean decrease: $0.49 \mathrm{mmol} / 1$

$\square$ control $\square 1700 \mathrm{mg} / \mathrm{kg} \mathrm{bw}$

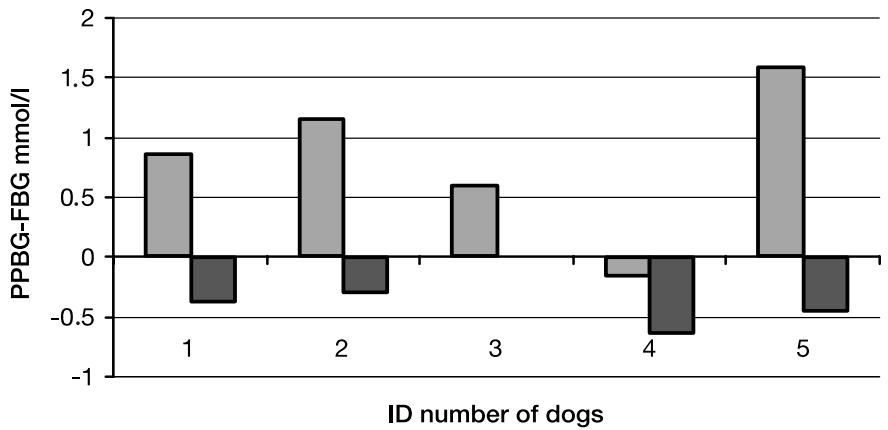

Fig. 2. Average blood glucose differences (PPBG-FBG) before and after treatment with $1700 \mathrm{mg}$ metformin in alloxan-diabetic dogs

$P$ value $=0.01$

Mean decrease: $1.15 \mathrm{mmol} / 1$

According to the statistical evaluation, of the investigated agents metformin was the only drug that caused a significant decrease in blood glucose level.

The haemogram of the dogs remained within the physiological range during the experimental period. In two cases transient eosinophilia (20\%) [reference range 1 - 6\% (Gaál 1999)] occurred in the metformin group, which was not proved to be associated with the treatment. 
$\square$ control $\square 160 \mathrm{mg} / \mathrm{kg} \mathrm{bw}$

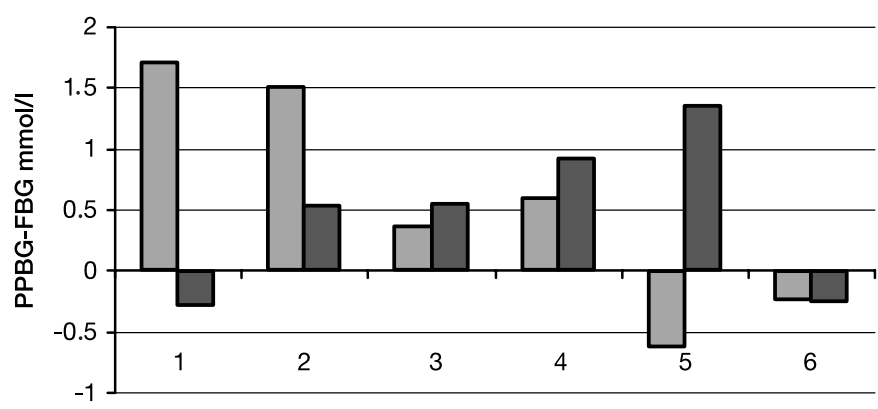

ID number of dogs

Fig. 3. Average blood glucose differences (PPBG-FBG) before and after treatment with $160 \mathrm{mg}$ gliclazide in alloxan-diabetic dogs

$P$ value $=0.01$

Mean decrease: $1.15 \mathrm{mmol} / 1$

Serum ALT, ALP, amylase and lipase activities as well as total cholesterol and triglyceride concentrations were also monitored.

In the acarbose group five dogs had moderately high ALP activity $(180-393 \mathrm{U} / \mathrm{L})$ [reference range: 30 - $140 \mathrm{U} / \mathrm{L}$ (Gaál 1999)], and three of them had somewhat higher amylase values too (1092 - $1387 \mathrm{U} / \mathrm{L})$ [reference range: below $900 \mathrm{U} / \mathrm{L}$ (Gaál 1999)] throughout the experimental period.

In the metformin group one dog initially had higher ALT and ALP activities (458 U/1 and $947 \mathrm{U} / 1$, respectively). Subsequently these values decreased gradually and returned to physiological values by the end of the experimental period. Amylase concentration in general rose in every dog but all values remained within the acceptable range.

In the gliclazide group, at the start of the study two dogs had higher ALT activity (144 and $991 \mathrm{U} / \mathrm{L}$ ) [reference range: below $40 \mathrm{U} / \mathrm{L}$ ] which gradually returned to previous values, while ALP activity was elevated (266 - $1640 \mathrm{U} / \mathrm{L})$ in five out of the six dogs. The higher initial amylase, ALT and ALP activities can be attributed to the alloxan treatment, which overloaded the hepatic capacity.

The plasma concentrations of lipase, TG and TC were within physiological range in all dogs throughout the experiment.

The insulin data remained within the reference range (36 - 144 pmol/l) (Kaneko et al. 1997 ) in the acarbose and metformin groups. In the gliclazide group, lower concentrations were also found in some cases (even $10.8 \mathrm{pmol} / \mathrm{l})$. No connection could be observed with the time course of the experiment, with the sampling times or with the general condition of the animals.

\section{Discussion}

Acarbose, metformin and gliclazide are oral antidiabetic drugs extensively used in human medicine either alone or in combination with one another or with insulin.

In veterinary practice, the sulphonylurea glipizide is considered to be a useful agent in cats, but there is hardly any evaluation in the literature regarding the place of oral antidiabetics in the management of diabetic dogs.

In addition to the characteristics of different species, the special physiological background should also be considered in the treatment of diabetes mellitus.

While type 1 DM requires insulin, type 2 in the early stage is not insulin-dependent, 
although with time pancreatic beta cells necrotise and insulin dependence evolves. In most cases the disease is recognised too late when insulin dependence has already developed.

Secondary diabetes of dogs provides some opportunity to use treatments other than insulin. The question remains as to whether there is a drug to be used.

Our experimental animals were treated with alloxan, an agent that selectively destroys beta cells. The damage of these cells is dose-dependent, so low dosages of alloxan can produce non-insulin-dependent diabetes mellitus (Cooperstein and Watkins 1981). Our experimental animals had moderately elevated FBG concentrations, which were also indicative of NIDDM.

Acarbose induced a statistically non-significant (close-to-significant) decrease in postprandial blood glucose compared to control. This drug slows the digestive and absorptive processes and thus a smaller amount of glucose enters the systemic circulation, reaching the pancreatic beta cells at lower concentrations (Coniff et al. 1995). According to the literature, insulin secretion was decreased in acarbose-treated healthy dogs, which could be attributed to the drug-induced delay in the absorption of carbohydrates (Robertson et al. 1999). The effect of acarbose can be influenced by the diet; namely, at higher carbohydrate content the drug can presumably exert a greater effect. Acarbose does not decrease hepatic glucose output or reverse any pathophysiological derangements in diabetic patients, and it is not absorbed systematically. In humans, acarbose is less effective in decreasing FBG than insulin, so it is prescribed as an initial and adjunctive therapy in obese patients although it reduces PPBG (Gerard et al. 1981; Dimitriadis et al. 1985; Rios 1994), blood glycosylated haemoglobin concentrations (Jenney et al. 1993; Coniff et al. 1995) and daily insulin requirements (Balfour and McTavish 1993; Rios 1994).

In healthy dogs, total insulin secretion was significantly decreased for $6 \mathrm{~h}$ after the administration of $100 \mathrm{mg}$ acarbose due to an indirect effect according to Robertson et al. (1999). Acarbose might exert its effect more slowly as there may be a threshold proportion of brush border enzymes that must be inhibited before the effects of acarbose can be identified (Robertson et al. 1999).

In humans, liver function enzyme activities may be elevated but this is resolved when the drug is discontinued (Cowan and Bunch 2001).

Transient changes in blood enzymes (elevated ALT and lipase) could be connected with drug administration and with alloxan treatment.

Acarbose acts at the "beginning" of glucose metabolism; namely, it can decrease the absorption of glucose from the gastrointestinal tract, but it does not directly influence either the insulin secretion or the glucose uptake of the cells. As the target of this drug is different, it would be worth studying in combination with insulin or metformin mainly in obese dogs (Nelson 2000).

On the basis of our data, the insulin sensitiser metformin significantly decreased the PPBG as compared to FBG.

The actual mode of action of metformin is not known, although it has several effects on glucose metabolism at different sites of action. It suppresses hepatic gluconeogenesis which can decrease fasting blood glucose (Baily and Turner 1996; DeFronzo 1999). Other authors attribute the acute effect of metformin on glucose production to the inhibition of hepatic gluconeogenesis (Chu et al. 2000). In our case FBG data remained on the same level (4.0-8.5 mmol/1) during the 4-5 weeks of the experiment. It remains a question whether the relative constancy of fasting blood glucose can be attributed to the fact that metformin does not influence hepatic gluconeogenesis in dogs, or that it can balance the constant loss of beta cells although insulin production did not change dramatically during the present experiment. Metformin presumably acts in different ways in dogs: it increases glucose uptake and oxidation in peripheral tissues, increases insulin receptor activity, delays 
glucose absorption from the bowel, and some of these effects result in a decrease in PPBG. Metformin improves insulin sensitivity in the peripheral tissues, but it is not effective in the absence of insulin (Stumvoll et al. 1995), although treatment with this drug has been reported to be associated with reduced plasma insulin, indicating that biguanides attenuate insulin resistance (Lenhard et al. 1997).

In our experimental model the sensitivity of insulin receptors was presumably not altered as in the case of a real type 2 diabetic patient. However, even in our experimental model metformin could significantly reduce the PPBG level. It did not decrease insulin secretion, which in our case was not originally high (as in the case of insulin resistance).

In view of the above facts, careful patient selection is important. Metformin can be appropriate for controlling pre-diabetic state in dogs with secondary diabetes mellitus, when insulin production still exists, e.g. in oestrous diabetes or in obese dogs with decreased glucose tolerance, until neutering or until dietary modifications restore the physiological balance in an optimal case.

Troglitazone, another drug belonging to the insulin sensitiser group, would also be worth studying as it acts in a way different from metformin: it promotes anabolism (it increases lipogenesis and mitochondrial mass while decreasing aerobic respiration and basal lipolysis), while metformin promotes catabolic processes (stimulates aerobic respiration, basal lipolysis and fatty acid oxidation) (Lenhard et al. 1997).

Gliclazide elicited no significant decrease in PPBG compared to FBG. Moreover, in three out of six dogs fasting blood glucose reached considerably high values $(22.4 \mathrm{mmol} / \mathrm{l}$ maximum) after the third week of treatment. Concerning another sulphonylurea derivative (glipizide) there are data in the literature that the likelihood of a response to glipizide treatment is inversely correlated with the degree of blood glucose elevation at the start of therapy (Turner et al. 1999). Stetinová et al. (2007) found that in alloxan-diabetic rats the decrease of glycaemia was smaller than in healthy animals after gliclazide administration, while the hypoglycaemic effect of gliclazide persisted longer in diabetic rats than in the control group.

In the dogs used in this study, hyperglycaemia gradually deteriorated in the course of treatment. So this case can rather be attributed to the progression of a pathological state. The disturbance of beta cell function also manifested itself in the occasional drop in insulin concentration.

The observed rise in ALP activity can be brought into connection with the pharmacokinetics of this drug: gliclazide is eliminated through the liver and the kidney. The elevation of liver enzyme activities in humans is usually resolved by temporary discontinuation of the drug.

In conclusion, metformin would be worth further studying in dogs. It would be important to characterise the type of diabetes in which this drug can be used and to determine the optimal dosage and probably a combination therapy.

\section{Vyhodnocení účinku p.o. podávaných léků snižujících hladinu glukózy v krvi u psů s diabetes mellitus indukovaným alloxanem}

Byl zkoumán účinek $\alpha$-glykosidázového inhibitoru akarbózy, antihyperglykemizujícího léku metforminu (zvyšujícího citlivost tkání na insulin) a gliclazidu, stimulujícího produkci inzulinu, na hladinu glukózy v krvi u psů s experimentálně vyvolaným diabetem. Psi byli náhodně rozděleni do 3 skupin. Během prvního (kontrolního) týdne experimentu byly testovány koncentrace glukózy v krvi. Během následujících pěti týdnů byla první skupině $(\mathrm{n}=6)$ podávána akarbóza $(200 \mathrm{mg}$ pro toto na den). Druhé skupině $(\mathrm{n}=5)$ byl podán metformin (1700 mg pro toto na den) a třetí skupině byl podán gliclazid (160 mg pro toto na den). Lék byl aplikován dvakrát denně při krmení, a to v 7 a 15 h. Průměrný rozdíl mezi koncentracemi glukózy nalačno a po krmení byl zjišt’ován v kontrolním týdnu 
a v průběhu experimentu. Statistická významnost rozdílu (průměrného poklesu) byla vyhodnocena pomocí párového $t$-testu. Průměrný pokles hladiny glukózy v krvi byl $0,49 \mathrm{mmol} \cdot \mathrm{l}^{-1}$ $(P=0,09)$ u akarbózy, $1,15 \mathrm{mmol} \cdot \mathrm{l}^{-1}(P=0,01)$ u metforminu a $0,08 \mathrm{mmol} \cdot \mathrm{l}^{-1}(P=0,88)$ u gliclazidu. Dle výsledků statistického vyhodnocení byl metformin jediným lékem, který vedl k významnému poklesu koncentrace glukózy v době po krmení.

\section{Acknowledgement}

Thanks are due to Ms. E. Szendrei, G. Okeke and K. Patikás for their excellent help in performing the animal phase of experiment. The precise laboratory work of Ms Zs. Móra and N. Misley is highly acknowledged. Appreciation goes to Dr. A. Székely for his excellent advice and generous help in the preparation of the manuscript.

This work was partly supported by the National Office for Research and Technology, National Scientific Research Fund (OTKA-T 049341).

\section{References}

BAILY CJ, TURNER RC 1996: Metformin. N Engl J Med 334: 574-578

BALFOUR JA, McTAVISH D 1993: Acarbose: an update of its pharmacology and therapeutic use in diabetes mellitus. Drugs 46: 1025-1054

BALLAGI-PORDÁNY G, KOLTAI MZ, ARANYI Z, POGÁTSA G 1991: Direct effect of hypoglycemic sulphonylureas on the cardiovascular system of dogs. Diabetes Res Clin Pract 11: 47-52

BEHREND EN 2002: Diabetes mellitus: an update on oral hypoglycemic agents and monitoring options. Vet Med 97: 743-751

BELCHER G, LAMBERT C, EDWARDS G, URQUHART R, MATTHEWS DR 2005: Safety and tolerability of pioglitazone, metformin, and gliclazide in the treatment of type 2 diabetes. Diabetes Res Clin Pract 70: 53-62

CHU CA, WIERNSPERGER N, MUSCATO N, KNAUF M, NEAL DW, CHERRINGTON AD 2000: The acute effect of metformin on glucose production in the conscious dog is primarily attributable to inhibition of glucogenolysis. Metabolism 49: 1619-1626

CONIFF RF, SHAPIRO JA, SEATON TB 1995: A double-blind placebo controlled trial evaluating the safety and efficacy of acarbose for the treatment of patients with insulin-requiring type II diabetes. Diabetes Care 18: $928-932$

COOPERSTEIN SJ, WATKINS D 1981: Action of toxic drugs on islet cells. In: COOPERSTEIN SJ, WATKINS D (Eds): The Islets of Langerhans. Academic Press, New York, pp. 387-425

COWAN SM, BUNCH SE 2001: Oral antidiabetic drugs for cats. Compend Contin Educ Pract Vet 23: 633-642

CUSI K, CONSOLI A, DeFRONZO RA 1996: Metabolic effects of metformin on glucose and lactate metabolism in noninsulin-dependent diabetes mellitus. J Clin Endocrinol Metab 81: 4059-4067

DeFRONZO RA 1999: Pharmacologic therapy for type 2 diabetes mellitus. Ann Intern Med 131: 281-303

DIMITRIADIS GD, TESSARI P, GO VL, GERICH JE 1985: Alpha-glucosidase inhibition improves postprandial hyperglycemia and decreases insulin requirements in insulin-dependent diabetes mellitus. Metabolism 34: 261-265

FÉRY F, PLAT L, BALASSE EO 1997: Effects of metformin on the pathways of glucose utilization after oral glucose in non-insulin-dependent diabetes mellitus patients. Metabolism 46: 227-233

FÖVÉNYI J, HALMOS T, POGÁTSA G 2001: Diabetology (in Hungarian). Springer, Budapest, 167 p.

GAÁL T (Ed.) 1999: Veterinary Clinical Laboratory Diagnostics (in Hungarian). Sík Kiadó, Budapest

GERARD J, LUYCKX AS, LEFEBVRE PJ 1981: Improvement of metabolic control in insulin dependent diabetics treated with the alpha-glucosidase inhibitor acarbose for two months. Diabetologia 21: 446-451

GODBOUT A, CHIASSON JL 2007: Who should benefit from the use of alpha-glucosidase inhibitors? Curr Diab Rep 7: 333-339

HANEFELD M, SCHAPER F 2008: Acarbose: oral anti-diabetes drug with additional cardiovascular benefits. Expert Rev Cardiovasc Ther 6: 153-163

JENNEY A, PROIETTO J, O’DEA K, NANKERVIS A, TRAIANEDES K, D'EMBDEN H 1993: Low-dose acarbose improves glycemic control in NIDDM patients without changes in insulin sensitivity. Diabetes Care 16: 499-502

KANEKO JJ, HARVEY JW, BRUSS ML 1997: Clinical Biochemistry of Domestic Animals. Academic Press, London, $932 \mathrm{p}$.

KECSKEMÉTI V, BAGI Z, PACHER P, POSA I, KOCSIS E, KOLTAI MZ 2002: New trends in the development of oral antidiabetic drugs. Curr Med Chem. 9: 53-71

LENHARD JM, KLIEWER SA, PAULIK MA, PLUNKET KD, LEHMAN JM, WEIEL JE 1997: Effects of troglitazone and metformin on glucose and lipid metabolism: alterations of two distinct molecular pathways. Biochem Pharmacol 54: 801-818

NELSON RW 2000: Oral medications for treating diabetes mellitus in dogs and cats. J Small Anim Pract 41 : 486-490 
NELSON RW, ROBERTSON J, FELDMAN EC, BRIGGS C 2000: Effect of the alpha-glucosidase inhibitor acarbose on control of glycemia in dogs with naturally acquired diabetes mellitus. J Am Vet Med Assoc 216: 1265-1269

PENTIKAINEN PJ, NEUVONEN PJ, PENTTILA A 1979: Pharmacokinetics of metformin after intravenous and oral administration to man. Eur J Clin Pharmacol. 16: 195-202

RIOS MS 1994: Acarbose and insulin therapy in type I diabetes mellitus. Eur J Clin Invest 24 (Suppl): 36-39

ROBERTSON J, NELSON R, KASS P, NEAL L 1999: Effects of the alpha-glucosidase inhibitor acarbose on postprandial serum glucose and insulin concentrations in healthy dogs. Am J Vet Res 60: 541-545

STETINOVÁ V, KVETINA J, PASTERA J, POLÁSKOVÁ A, PRAZÁKOVÁ M 2007: Gliclazide: pharmacokinetic-pharmacodynamic relationships in rats. Biopharm Drug Dispos 28: 241-248

STUMVOLL M, NURJHAN N, PERIELLO G, DAILEY G, GERICH JE 1995: Metabolic effects of metformin in non-insulin dependent diabetes mellitus. N Engl J Med 333: 550-554

TURNER RC, CULL CA, FRIGHI V, HOMAN RR 1999: The UK Prospective Diabetes Study Group. J Am Med Assoc 281: 2005-2012 
